Corrigendum: The resistance of DMC1 D-loops to dissociation may account for the DMC1 requirement in meiosis

Dmitry V Bugreev, Roberto J Pezza, Olga M Mazina, Oleg N Voloshin, R Daniel Camerini-Otero \& Alexander V Mazin Nat. Struct. Mol. Biol. 18, 56-60 (2011); doi:10.1038/nsmb.1946; published online 12 December 2010; corrected after print 9 August 2011 and 10 October 2012

In the version of this article initially published, support from the Oklahoma Center for the Advancement of Science and Technology to R.J.P. was not acknowledged. The error has been corrected in the PDF and HTML versions of this article.

\title{
Erratum: Tudor domain ERI-5 tethers an RNA-dependent RNA polymerase to DCR-1 to potentiate endo-RNAi
}

Caroline Thivierge, Neetha Makil, Mathieu Flamand, Jessica J Vasale, Craig C Mello, James Wohlschlegel, Darryl Conte Jr \& Thomas F Duchaine

Nat. Struct. Mol. Biol. 19, 90-97 (2012); published online 18 December 2011; corrected after print 9 January 2012

In the version of this article initially published, information in Table 1 was inaccurate. "Newly described" should have been "novel" and "Argonaute protein domain" should have read "Argonaute protein." The errors have been corrected in the HTML and PDF versions of the article.

\section{Erratum: The spindle-assembly checkpoint and the beauty of self-destruction} Andrea Musacchio \& Andrea Ciliberto Nat. Struct. Mol. Biol. 19, 1059-1061 (2012); published online 6 November 2012; corrected after print 20 December 2012

In the version of this article initially published, in the lower part of Figure 2, the upper arrow connecting Cdc20 to the APC/C to form APC/C Cdc20 pointed in the wrong direction. The error has been corrected in the HTML and PDF versions of the article.

Corrigendum: H3K36me3 key to Polycomb-mediated gene silencing in lineage specification

Jumana AlHaj Abed \& Richard S. Jones

Nat. Struct. Mol. Biol. 19, 1214-1215 (2012); published online 5 December 2012; corrected after print 20 December 2012

In the version of this article initially published, the first author's name in ref. 3 was given as 'Brein'; the correct spelling is 'Brien'. The error has been corrected in the HTML and PDF versions of the article.

\section{Erratum: Telomere length regulates TERRA levels through increased trimethylation of telomeric H3K9 and HPl $\alpha$}

Nausica Arnoult, Amandine Van Beneden \& Anabelle Decottignies

Nat. Struct. Mol. Biol. 19, 948-956 (2012); published online 26 August 2012; corrected after print 27 December 2012

In the version of this article initially published, the colors in the key in Figure 7c were incorrectly reversed. Red should have represented telomeres and gray $\alpha$-satellite regions. The error has been corrected in the HTML and PDF versions of the article.

\section{Corrigendum: A transcription factor-based mechanism for mouse heterochromatin formation}

Aydan Bulut-Karslioglu, Valentina Perrera, Manuela Scaranaro, Inti Alberto de la Rosa-Velazquez, Suzanne van de Nobelen, Nicholas Shukeir, Johannes Popow, Borbala Gerle, Susanne Opravil, Michaela Pagani, Simone Meidhof, Thomas Brabletz, Thomas Manke, Monika Lachner \& Thomas Jenuwein

Nat. Struct. Mol. Biol. 19, 1023-1030 (2012); published online 16 September 2012; corrected after print 27 December 2012

In the version of this article initially published, Simone Meidhof's affiliations should have included Spemann Graduate School of Biology and Medicine (SGBM), Albert Ludwigs University Freiburg, Freiburg, Germany and the Faculty of Biology, Albert Ludwigs University Freiburg, Freiburg, Germany. Acknowledgement of the Excellence Initiative of the German Research Foundation (GSC-4, Spemann Graduate School) was omitted. The errors have been corrected in the HTML and PDF versions of the article. 